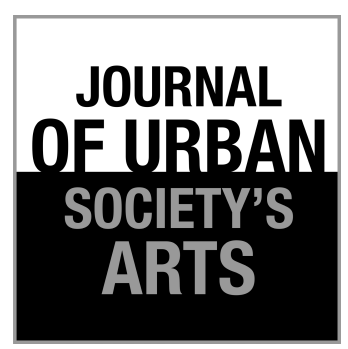

Volume 3 Nomor 1 , April 2016: 27-36

\section{Memaknai Nilai Kesenian Kuda Renggong dalam Upaya Melestarikan Budaya Daerah di Kabupaten Sumedang}

Pratiwi Wulan Gustianingrum dan Idrus Affandi

Prodi Kewarganegaraan, Sekolah Pascasarjana

Universitas Pendidikan Indonesia, Bandung

Tlp. 081220201883/085720123885, E-mail:wg.pratiwi@yahoo.co.id

\begin{abstract}
ABSTRAK
Penelitian ini bertujuan untuk memaknai nilai kesenian Kuda Renggong dalam upaya melestarikan budaya daerah di Kabupaten Sumedang. Penelitian ini menggunakan pendekatan kualitatif dengan metode studi kasus. Data dikumpulkan melalui observasi, wawancara, dan studi dokumentasi. Nilai-nilai yang terkandung dalam kesenian Kuda Renggong antara lain: spiritual/religius, interaksi antarmakhluk Tuhan, teatrikal, estetika, kerja sama, kekompakan dan ketertiban, kerja keras dan ketekunan, dan sosial. Kesenian ini secara tidak langsung membentuk karakter manusia/masyarakat menjadi lebih baik. Hal ini ditunjukkan lewat tindakan kerja bersama, saling menghargai satu dan yang lain, kebersamaan, ketekunan, ketertiban, dan semangat religius yang tinggi sebagai ungkapan rasa syukur terhadap Tuhan Yang Maha Esa. Pelestarian kesenian ini didukung oleh Pemerintah Daerah Kabupaten Sumedang, seniman, dan masyarakat.
\end{abstract}

Kata kunci: pelestarian budaya, kesenian Sumedang, Kuda Renggong

\begin{abstract}
Interpreting the Art Value of Kuda Renggong in Preserving the Local Culture in Kabupten Sumedang. The research aims to interpret the art value of Kuda Renggong in preserving the the local culture in Sumedang. The research uses qualitative approach with a case study as the research method. The subject of research covers the Local Government of Sumedang, PASKURES and society. The data collection techniques use the observation, interviews, and documentation. Kuda Renggong contains some values such as: spirituall religious values, the value of the interaction among the God's creatures, theatrical value, universal value, aesthetic value, cooperative value, cohesiveness and order value, hard work and perseverance value, and social value. Kuda Renggong indirectly forms human or social character better. It can be shown through out the team-work action, mutual appreciation, togetherness, perseverance, discipline, and high religious spirit as the expression to thank to God the almighty. The preservation of Kuda Renggong is supported by the government of Sumedang Regency, artists, and the society.
\end{abstract}

Keywords: culture preservation, Sumedang art, Kuda Renggong

\section{Pendahuluan}

Kesenian merupakan hasil dari kebudayaan manusia yang dapat didokumentasikan atau dilestarikan, dipublikasikan, dan dikembangkan sebagai salah satu upaya menuju kemajuan peradaban dan mempertinggi derajat kemanusian bangsa dengan mengangkat kebudayaan daerah. Pada dasarnya perkembangan seni mutakhir kini, sering disebut sebagai perkembangan seni kontemporer, telah disebutkan tidak dapat dipisahkan dari sistem sosial, ekonomi dan budaya 
sebuah masyarakat; tetapi juga secara khas mampu menunjukkan manifestasi estetik dan refleksi nilai yang bersifat kritis terhadap sistem ekonomi sosial kultural yang menghidupinya (Himawan \& Nugroho 2014:100). Hal itu dapat meningkatkan penghayatan terhadap nilai-nilai luhur budaya bangsa. Nilai-nilai budaya tersebut berguna dalam pembentukan keperibadian atau karakter warga negara.

Membangun karakter warga negara merupakan hal yang sangat penting untuk menjaga eksistensi suatu bangsa atau negara. Eksistensi suatu bangsa bisa tetap bertahan apabila bangsa tersebut memiliki identitas yang kuat. Identitas adalah sebuah isu yang mempertanyakan kesadaran terhadap diri atau subjek, melalui pertanyaan-pertanyaan yang bertumpu pada satu pertanyaan,"Siapa aku?" Pertanyaan ini kemudian mengarahkan pada berbagai macam pendefinisian mengenainya (Himawan, 2014:84). Identitas suatu bangsa bisa tercermin dari budaya bangsa itu sendiri. Dalam hal ini tidaklah mengherankan jika pada awal kemerdekaan, Presiden Soekarno telah menekankan prinsip berdaulat politik, berdiri di kaki sendiri (berdikari) dalam ekonomi dan kepribadian dalam kebudayaan. Karakter warga negara hingga saat ini belum menunjukkan karakter yang baik, seperti banyaknya perilaku warga negara yang menyimpang dari nilai-nilai moral dan norma yang sesuai dengan kepribadian bangsa ini.

Kesenian dan kebudayaan merupakan dua sisi mata uang yang tidak terpisahkan. Kesenian dapat menjadi wadah untuk mempertahankan identitas budaya Indonesia. Faktanya, sekarang ini identitas budaya Indonesia sudah mulai memudar karena arus global sehingga kondisi yang mengkhawatirkan ini perlu segera diselamatkan.

Indonesia terutama budaya daerahnya berada di tengah arus globalisasi dewasa ini. Era globalisasi ditandai oleh adanya saling kebergantungan antarnegara. Hal ini adalah suatu hal yang tidak bisa dihindari, sebagai konsekuensi dari semakin longgarnya batas negara. Dunia menjadi tanpa batas yang ditandai dengan tidak terhambatnya arus orang, barang, dan jasa (Widodo, 2009) - Berkembangnya arus globalisasi tidak dapat dipungkiri akan membawa dampak baik positif maupun negatif di segala bidang kehidupan. Berdampak positif, ketika globalisasi dapat membantu manusia dalam menyelesaikan segala kebutuhannya, namun juga berdampak negatif ketika globalisasi dapat mengikis kebudayaan yang menjadi ciri khas dari suatu bangsa. Hal tersebut sesuai dengan pendapat bahwa globalisasi menimbulkan berbagai masalah dalam bidang kebudayaan, misalnya hilang budaya asli suatu daerah atau suatu negara, terjadi erosi nilainilai budaya, menurun rasa nasionalisme dan patriotisme, hilang sifat kekeluargaan dan gotong royong, kehilangan kepercayaan diri, gaya hidup yang tidak sesuai dengan adat kita (Suneki, 2012) .

Sejalan dengan perkembangan zaman itu pula, keberadaan nilai-nilai budaya Sunda seperti dalam penelitian ini mulai tergeser fungsi dan peranannya di dalam masyarakat. Salah satu penyebabnya adalah karena terhambatnya proses transfusi dari generasi tua kepada generasi selanjutnya.

Dalam hal ini maka upaya pelestarian mutlak diperlukan guna berjalannya proses pembentukan karakter warga negara suatu bangsa. Kesadaran akan pentingnya pengelolaan dan pelestarian warisan budaya kini sudah semakin tinggi, bahkan banyak di antara pencinta dan pemerhati warisan budaya yang berkeyakinan bahwa sumber daya budaya itu tidak saja merupakan warisan, tetapi lebih-lebih adalah pusaka bagi bangsa Indonesia. Artinya, sumber daya budaya itu mempunyai kekuatan yang dapat dimanfaatkan untuk membantu dan melindungi bangsa ini dalam menapaki jalan ke masa depan. Warisan budaya sebagai suatu pusaka bangsa harus tetap dijaga agar kekuatannya tidak hilang dan dapat diwariskan kepada generasi penerus tanpa berkurang nilainya. Pelestarian budaya daerah tersebut penting dilakukan karena nilai-nilai sosiokultural dapat dijadikan norma yang mengatur tingkah laku seseorang dalam kelompok, membuat seseorang sensitif terhadap status, dan membantunya mengetahui apa yang diharapkan orang lain terhadap dirinya dan apa yang akan terjadi jika tidak memenuhi harapanharapan mereka (Lonto, 2015:325) . Pendapat lain juga mengemukakan identitas kultural biasanya dirasakan sangat penting bagi masyarakat/bangsa bersangkutan di mana pun terutama oleh karena 
identitas kultural dapat berfungsi, selain sebagai penanda atau pembeda, juga berfungsi sebagai pengikat kebersamaan (yang mempersatukan segenap warga komunitas), sebagai kekayaan dan kebangsaan (warisan budaya yang memberikan semacam roh, yang karena itu harus senantiasa dipelihara, dilestarikan, dan dikembangkan), dan sebagai kekuatan, yakni kekuatan penggerak dalam kehidupan dan mencapai tujuan baik secara internal sesama warga komunitas maupun eksternal ketika berinteraksi dengan masyarakat lain (Parwito \& Drajat, 2013:113) .

Tentunya dengan melihat pentingnya suatu budaya dalam kelangsungan suatu bangsa itu sendiri maka pelestarian budaya lokal itu mutlak diperlukan dan dilakukan oleh masyarakat guna mengukuhkan budaya daerah agar tidak punah. Apalagi dalam Undang Undang Dasar Negara RI tahun 1945 (UUD 1945) Pasal 32 ayat (1) dinyatakan, "Negara memajukan kebudayaan nasional di tengah peradaban dunia dengan menjamin kebebasan masyarakat dalam memelihara dan mengembangkan nilai-nilai budayanya”. Dalam hal ini sudah sangat jelas bahwa konstitusi menugaskan kepada penyelenggara negara untuk memajukan kebudayaan nasional Indonesia. Hal ini berarti negara berkewajiban memberi ruang, waktu, sarana, dan institusi untuk memajukan kebudayaan nasional dari mana pun budaya itu berasal.

Fokus penelitian ini adalah: (1) nilai-nilai yang terkandung dalam kesenian Kuda Renggong yang merupakan budaya daerah asli dari Kabupaten Sumedang; (2) peranan kesenian Kuda Renggong dalam pembentukan karakter warga negara; dan (3) peranan masyarakat dan pemerintah daerah dalam melestarikan budaya daerah khususnya dalam melestarikan kesenian Kuda Renggong di Kabupaten Sumedang.

Penelitian ini menggunakan pendekatan kualitatif dengan metode studi kasus. Subjek penelitian ini meliputi kepala Pemerintah Daerah Kabupaten Sumedang, seniman Kuda Renggong, dan masyarakat umum. Data dikumpulkan melalui observasi, wawancara, dan studi dokumentasi. Analisis dalam penelitian ini menggunakan model Miles \& Huberman (2007:16-18). Teknis analisis tersebut terdiri dari reduksi data, penyajian data, dan verifikasi data. Data yang diperoleh divalidasi menggunakan teknik triangulasi sumber.

\section{Kuda Renggong sebagai Kesenian Asli dari Sumedang}

Kuda Renggong merupakan seni pertunjukan gelaran (pawai). Kuda Renggong merupakan salah satu pertunjukan rakyat yang berasal dari Kabupaten Sumedang. Menurut tuturan beberapa seniman, Kuda Renggong muncul pertama kali dari Desa Cikurubuk, Kecamatan Buahdua, Kabupaten Sumedang. Bahkan kesenian Kuda Renggong telah didaftarkan di Balai Pelestarian Budaya Provinsi Jawa Barat sebagai kesenian unggulan dari Kabupaten Sumedang yang wajib dilestarikan.

Kata renggong di dalam kesenian ini merupakan metatesis dari kata ronggeng, yaitu kamonesan (bahasa sunda untuk "keterampilan") cara berjalan kuda yang telah dilatih untuk menari mengikuti irama musik (terutama kendang) yang biasanya dipakai sebagai media tunggangan dalam arak-arakan anak sunat. Kuda Renggong merupakan seni pertunjukan tradisional yang sangat populer di Kabupaten Sumedang. Atraksi ini berupa pertunjukan seekor kuda yang terlatih melakukan gerakan menari dan berjalan mengikuti hentakan musik tradisional sunda yang disebut kendang pencak. Seekor kuda dilatih dengan baik untuk membuat gerakan seperti menari atau kadang juga melakukan gerakan seperti berkelahi melawan pelatihnya dengan gaya pencak silat. Pertunjukan ini oleh sebab itu juga sering disebut dengan pertunjukan kuda pencak.

Kesenian Kuda Renggong di Kabupaten Sumedang mulai muncul sekitar tahun 1910. Hingga sekarang, kesenian ini secara tradisional sering dipertontonkan dalam acara khitanan/ sunatan yang digolongkan dalam pertujukan di pemukiman. Pertunjukan ini diadakan setelah anak sunat diupacarai dan diberi doa, lalu dengan berpakaian seperti wayang tokoh Gatotkaca, pakaian pangeran khas sunda dengan ciri menggunakan bendo (sejenis topi mirip blangkon. Sang anak kemudian diarak mengelilingi kota di atas punggung Kuda Renggong diikuti oleh anggota 
keluarga dan kerabat dekat yang ikut menari di depannya dan berkeliling dari satu desa ke desa lainya dengan diiringi musik pengiring yang penuh semangat dengan tembang-tembang yang dipilih seperti kembang beureum, kembang gadung, dan lagu khas seni bangreng Kuda Renggong. Di sepanjang jalan, Kuda Renggong bergerak menari dikelilingi oleh anak-anak, remaja dewasa, dan orang-orang tua yang ikut kaul. Setelah berkeliling desa, rombongan Kuda Renggong kembali ke rumah anak sunat yang biasanya dengan diiringi lagu pileuleuyan (perpisahan).

\section{Nilai-Nilai dan Peranan Kesenian Kuda Renggong dalam Pembentukan Karakter Warga Negara}

Nilai seni budaya daerah merupakan nilainilai yang terkandung dalam budaya daerah itu sendiri. Nilai budaya tidak mudah diganti ataupun dihilangkan karena nilai budaya seperti yang telah diungkapkan di atas merupakan sesuatu yang baik dan dianggap bernilai dan dijadikan sebagai pedoman bertingkah laku. Dalam kesenian Kuda Renggong ternyata juga terdapat nilai-nilai luhur yang harus dilestarikan. Nilai-nilai luhur tersebut adalah (1) Nilai spiritual/religius: semangat yang dimunculkan dalam rangkaian upacara inisiasi (pendewasaan) dari seorang anak laki-laki yang disunat. Kekuatan Kuda Renggong yang tampil akan membekas di sanubari anak sunat, juga pemakaian kostum tokoh wayang Gatotkaca yang dikenal sebagai figur pahlawan; (2) nilai interaksi antarmakhluk Tuhan: kesadaran para pelatih Kuda Renggong dalam memperlakukan kudanya, tidak semata-mata seperti layaknya pada binatang peliharaan, tetapi memiliki kecenderungan memanjakan bahkan memosisikan kuda sebagai makhluk Tuhan yang dimanjakan, baik dari pemilihan, makanannya, perawatannya, pakaiannya, dan lain-lain; (3) nilai teatrikal: pada saat-saat tertentu di kala Kuda Renggong bergerak ke atas seperti berdiri lalu di bawahnya juru latih bermain silat, kemudian menari dan bersilat bersama. Kuda Renggong terlihat teatrikal karena posisi kuda yang lebih tampak berwibawa dan memesona. Atraksi ini merupakan sajian yang langka karena tidak semua Kuda Renggong mampu melakukannya; (4) nilai universal: sejak zaman manusia mengenal binatang kuda, telah menjadi bagian dalam hidup manusia di berbagai bangsa di berbagai tempat di dunia. Kuda bahkan banyak dijadikan simbol kekuatan, kejantanan, kepahlawanan, kewibawaan, dan lain-lain; (5) nilai estetika: dalam kesenian Kuda Renggong memang terdapat keindahan yang diperlihatkan melalui pakaian yang dipakai oleh Kuda Renggong yang meriah termasuk juga anak yang menungganginya, pemain musik serta penari pengiringnya; (6) nilai kerja sama: dalam kesenian Kuda Renggong terlihat dari adanya kebersamaan dalam melestarikan warisan budaya para pendahulunya; (7) nilai kekompakan dan ketertiban: tercermin dalam suatu pementasan yang dapat berjalan secara lancar; (8) nilai kerja keras dan ketekunan: dalam kesenian Kuda Renggong nilai tersebut tercermin dari penguasaan gerakan-gerakan tarian; dan (9) nilai sosial: dalam kesenian Kuda Renggong ini rasa sosial masyarakat memang sangat terasa dengan saling peduli dan membantu dalam proses pelaksanaan kesenian ini.

Nilai-nilai budaya yang terkandung dalam kesenian Kuda Renggong tersebut merupakan nilai-nilai yang sering tercermin dalam kehidupan sehari-hari. Nilai-nilai tersebut dari dahulu sampai sekarang masih terpelihara dengan baik dan dapat diterima oleh masyarakat sebagai bagian dari budaya mereka yang patut untuk dijaga dan dilestarikan. Hal tersebut sesuai dengan nilai-nilai dimaksudkan oleh Soekamto (1983) bahwa nilai merupakan ukuran-ukuran patokan keyakinan yang dianut orang banyak di dalam lingkungan suatu kebudayaan tertentu, mengenai apa yang benar, pantas dan baik untuk dikerjakan dan diperhatikan. Berdasarkan pendapat tersebut bahwa nilai itu sebagai sesuatu yang baik yang patut untuk dikerjakan dan diperhatikan bahkan harus dilestarikan masyarakat.

Dalam kajian filsafat pada umumnya terdapat prinsip-prinsip untuk pemilihan nilai yang sesuai dengan pendapat Munandar (Utami, 2015) antara lain nilai intrinsik harus mendapat prioritas pertama daripada nilai ekstrinsik yang maksudnya sesuatu yang berharga secara intrinsik, yaitu baik 
dari dalam dirinya sendiri dan bukan karena menghasilkan sesuatu yang lain. Nilai-nilai yang produktif dan secara relatif bersifat permanen didahulukan daripada nilai yang kurang produktif dan kurang permanen. Dapat disimpulkan bahwa nilai intrinsik adalah sebuah nilai yang berasal dari dalam objek tertentu, sedangkan nilai ekstrinsik, yaitu nilai yang berasal dari luar objek tersebut. Nilai yang produktif akan lebih memiliki makna yang mendalam.

Nilai-nilai seni budaya yang terdapat dalam kesenian Kuda Renggong tersebut sesuai juga dengan beberapa pendapat para ahli yang dikutip oleh Suhaida (2014), yang mengidentifikasi macam-macam nilai yang selama ini telah tumbuh dan berkembang di masyarakat seperti tercantum dalam tabel 1 .

Nilai-nilai yang terkandung di dalam kesenian Kuda Renggong sesuai dengan yang dirumuskan oleh para ahli. Nilai-nilai tersebut saling berkaitan satu sama lain sehingga dalam menjalankan hidup berdampingan dengan sesama manusia terjalin dengan harmonis dan mencerminkan masyarakat yang berkarakter.

Menurut Koentjaraningrat (1974), kebudayaan dapat didukung sebagian besar warga dari suatu Negara. Maka, sebagai syarat mutlak sifatnya harus khas dan harus dapat dibanggakan oleh warga negara yang mendukung. Setiap kebudayaan yang berkembang dalam masyarakat memiliki nilai dan fungsi tertentu. Nilai-nilai budaya berfungsi sebagai pedoman hidup manusia dalam masyarakat yang merupakan konsep-konsep mengenai apa yang hidup di alam pikiran sebagian besar warga masyarakat mengenai apa yang mereka anggap bernilai, berharga, dan penting dalam hidup (Koentjaraningrat, 1994). Berdasarkan pendapat di depan dapat disimpulkan bahwa nilai-nilai yang terkandung dalam suatu budaya dapat menjadi pedoman masyarakat dalam berperilaku

\begin{tabular}{|c|c|}
\hline No. $\quad$ Nama Tokoh & Pendapat \\
\hline 1. Alport & $\begin{array}{l}\text { Mengidentifikasi nilai-nilai yang terdapat dalam kehidupan masyarakat, } \\
\text { dalam enam macam, yaitu: } \\
\text { a. nilai teori } \\
\text { b. nilai ekonomi } \\
\text { c. nilai estetika } \\
\text { d. nilai sosial } \\
\text { e. nilai politik } \\
\text { f. nilai religi }\end{array}$ \\
\hline 2. Sprange & $\begin{array}{l}\text { Nilai dapat dibedakan menjadi enam, yaitu: } \\
\text { a. nilai ilmu pengetahuan } \\
\text { b. nilai ekonomi } \\
\text { c. nilai agama } \\
\text { d. nilai seni } \\
\text { e. nilai sosial } \\
\text { f. nilai politik }\end{array}$ \\
\hline 3. Sprange, Harold Lasswell & $\begin{array}{l}\text { Mengidentifikasi delapan nilai-nilai masyarakat Barat dalam hubungan- } \\
\text { nya dengan manusia lainnya, yaitu: } \\
\text { a. kekuasaan } \\
\text { b. pendidikan/ penerangan (enlightenment) } \\
\text { c. kekayaan (wealth) } \\
\text { d. kesehatan (well-being) } \\
\text { e. keterampilan (skill) } \\
\text { f. kasih sayang (affection) } \\
\text { g. kejujuran (rectitude) dan keadilan (rechtshapenheid) } \\
\text { h. keseganan, respek (respect) }\end{array}$ \\
\hline
\end{tabular}


dan membentuk karakter warga masyarakat dan tentunya menjadi identitas dari suatu warga masyarakat itu sendiri. Dalam hal ini menjadi sangat penting masyarakat dalam melestarikan budayanya sendiri guna membentuk karakter warga negara itu sendiri.

Pembentukan karakter warga negara yang kokoh akan mampu mengatasi masalah yang berhubungan dengan paham golongan, suku, agama, budaya yang kesemuanya sangat rentan terhadap konflik yang merugikan bagi integritas nasional. Dalam hal ini yang terpenting adalah membentuk karakter warga negara itu harus dimulai sejak dini dan terus berkelanjutan sehingga menghasilkan generasi muda dan pemimpin bangsa yang memiliki semangat integritas yang tinggi.

Karakter bangsa merupakan akumulasi dari karakter-karakter warga masyarakat bangsa itu. Karakter merupakan nilai dasar perilaku yang menjadi acuan tata nilai interaksi antarmanusia, yang when character is lost then everything is lost. Karakter secara universal dirumuskan sebagai nilai hidup bersama berdasarkan pilar: kedamaian, menghargai, kerjasama, kebebasan, kebahagiaan, kejujuran, kerendahhatian, kasih sayang, tanggung jawab, kesederhanaan, toleransi, dan persatuan (Gufron 2010) . Konsep karakter warga negara tersebut hampir sebagian besar terwujud dalam kesenian Kuda Renggong.

Membentuk suatu karakter di suatu negara sangatlah penting dilakukan sebab negara yang besar adalah negara yang memiliki karakter yang baik. Karakter yang baik menjadikan kehidupan dalam negara tersebut akan damai dan tentram. Apabila karakter warga negaranya buruk maka realita kehidupan negara tersebut akan tidak baik pula. Karakter bangsa Indonesia akan muncul pada saat seluruh komponen bangsa menyatakan perlunya perilaku kolektif kebangsaan yang unik, baik yang tercermin dalam kesadaran, pemahaman, rasa, karsa, dan perilaku berbangsa dan bernegara dari hasil olah pikir, olah rasa dan karsa, olah hati serta olah raga seseorang atau sekelompok orang bangsa Indonesia (Budimansyah, 2012) .

Perubahan dinamis dan arus globalisasi yang tinggi menyebabkan masyarakat Indonesia yang memiliki banyak dan beragam kebudayaan kurang memiliki kesadaran akan pentingnya peranan budaya lokal ini dalam memperkokoh ketahanan budaya bangsa. Budaya lokal yang dimiliki ini sesungguhnya dapat menjadikan bangsa Indonesia lebih bernilai dibandingkan bangsa-bangsa lain dan seharusnya bisa lebih tanggap dan peduli lagi terhadap semua kebudayaan yang ada di Indonesia.

Langkah yang lainnya yaitu harus memahami arti kebudayaan dan menjadikan keanekaragaman budaya yang ada di Indonesia sebagai sumber kekuatan untuk ketahanan budaya bangsa agar tetap terjaga dan tidak diambil oleh bangsa lain. Kekayaan bangsa Indonesia ini tidak ternilai harganya dan tidak pula dimiliki oleh bangsa-bangsa asing. Sebagai generasi muda yang merupakan pewaris budaya bangsa hendaknya memelihara seni budaya demi masa depan bangsa ini.

Setiap kebudayaan yang berkembang dalam masyarakat memiliki nilai dan fungsi tertentu. Nilai-nilai budaya berfungsi sebagai pedoman hidup manusia dalam masyarakat yang merupakan konsep-konsep mengenai apa yang hidup di alam pikiran sebagian besar warga masyarakat mengenai apa yang mereka anggap bernilai, berharga, dan penting dalam hidup (Koentjaraningrat, 1994) .

Kesenian Kuda Renggong secara tidak langsung membentuk karakter manusia/masyarakat menjadi lebih baik. Hal ini ditunjukkan lewat tindakan kerja bersama, saling menghargai satu dan yang lain, kebersamaan, ketekunan, ketertiban, dan semangat religius yang tinggi sebagai ungkapan rasa syukur terhadap Tuhan Yang Maha Esa. Kesenian Kuda Renggong juga memenuhi karakteristik yang harus dimiliki oleh warga negara menurut beberapa ahli seperti telah disebutkan. Salah satu karakter yang paling menonjol ada melalui kesenian Kuda Renggong antara lain memiliki karakteristik rasa saling menghormati dan tanggung jawab terhadap pluralitas yang ada dalam masyarakat Indonesia yang terdiri dari suku bangsa, ras, keyakinan beragama, dan idelogi politik. Dalam Kesenian Kuda Renggong juga terdapat kemampuan bekerja sama dengan yang lain dengan cara yang kooperatif dan menerima tanggung jawab atas peran/tugasnya di dalam masyarakat. Jadi, begitu pentingnya masyarakat dalam melestarikan budayanya sendiri guna membentuk karakter warga negara itu sendiri. 


\section{Peranan Masyarakat dan Pemerintah dalam Melestarikan Kesenian Kuda Renggong}

Partisipan seni adalah pelaku yang terlibat baik secara langsung maupun tidak langsung dalam perkembangan seni dalam masyarakatnya Dalam masyarakat tradisional, partisipan yang terlibat dalam kesenian, bisa bersifat individu, atau semua anggota masyarakat (Ardipal, 2015:16) . Hal ini berarti sejalan dengan apa yang menjadi citacita dari Pemerintah Kabupaten Sumedang yang berupaya dalam melestarikan budaya daerah, dan ini dibuktikan dengan dibuatnya Peraturan Bupati Nomor 113 Tahun 2009 Tentang Sumedang Puseur Budaya Sunda (SPBS). Keadaan ini membuktikan bahwa Pemerintah Daerah Kabupaten Sumedang sangat peduli terhadap kelangsungan dan perkembangan kesenian unggulan di Kabupaten Sumedang.

Upaya-upaya yang dilakukan oleh Pemerintah Daerah Kabupaten Sumedang yang didapat dari hasil observasi, wawancara, dan studi dokumentasi antara lain: (1) membuat Peraturan Bupati Nomor 113 Tahun 2009 Tentang Sumedang Puseur Budaya Sunda (SPBS); (2) Kesenian Kuda Renggong biasanya digunakan dalam acara-acara Pemerintah Daerah dalam menyambut tamu undangan (gegeden atau inohong); (3) Dinas Pariwisata, Pemuda, dan Olahraga (DISPARPORA) telah mempunyai agenda rutin mengadakan festival Kuda Renggong setiap tahun pada bulan September yang bertempat di Alun-Alun Kabupaten Sumedang; (4) DISPARPORA memiliki event festival Kuda Renggong Jatinunggal; (5) DISPARPORA juga rutin mengadakan festival kesenian lainnya seperti

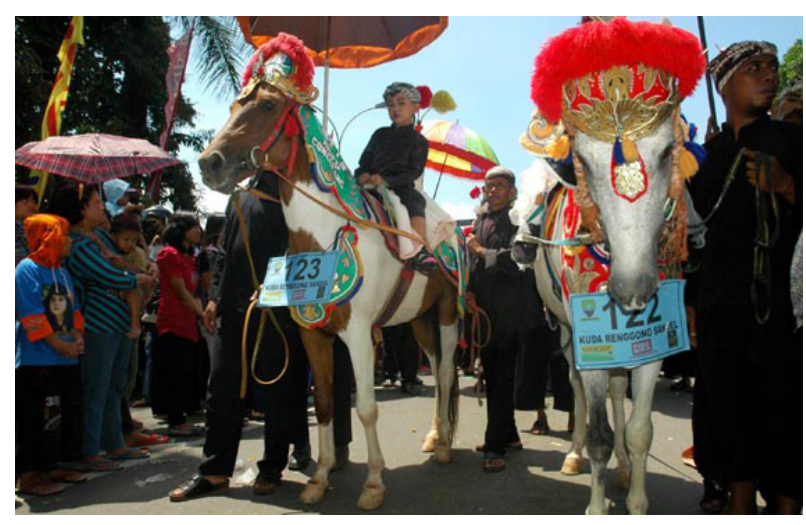

Gambar 1. Festival Kuda Renggong Kabupaten Sumedang. festival Tarawangsa, Gembyung serta yang paling baru rencana akan dibuatnya festival Jatigede; dan (6) Dinas Pendidikan dan Kebudayaan (DISDIKBUD) juga sering mengadakan promosi mengenai budaya daerah Kabupaten Sumedang dengan membuat brosur-brosur, promosi baik melalui media cetak maupun media elektronik.

Selain upaya yang dilakukan Pemerintah Daerah Kabupaten Sumedang, tokoh seniman Kuda Renggong juga telah berinisiatif dan dibentuklah PASKURES (Paguyuban Seni Kuda Renggong Kabupaten Sumedang) pada tahun 2014 yang telah berbadan hukum. PASKURES diketuai oleh Encep (mantan Kuwu Desa Pasir Reungit, Kecamatan Paseh). Anggota dari PASKURES ini telah mencapai lebih dari 1000 orang seniman Kuda Renggong yang tersebar di berbagai wilayah Kabupaten Sumedang dengan tujuan untuk menyatukan dan memfasilitasi para seniman Kuda Renggong. PASKURES juga mengadakan festival Kuda Renggong tingkat daerah pada 22 Mei 2016 di Lapangan Pacuan Kuda Sumedang. Kondisi ini membuktikan selain kepedulian dari Pemerintah Daerah Kabupaten Sumedang seniman Kuda Renggong itu sendiri juga mendukung program dari Pemerintah Kabupaten Sumedang untuk melestarikan seni budaya daerah sendiri.

Di samping Pemerintah Daerah Kabupaten Sumedang dan para seniman Kuda Renggong, tidak kalah penting juga partisipasi masyarakat yang tentunya sangat membantu dalam pelestarian budaya daerah itu. Hasil penelitian memperlihatkan bahwa masyarakat yang justru paling dominan dan antusis melestarikan kesenian Kuda Renggong tersebut. Keadaan tersebut ditandai dengan selalu

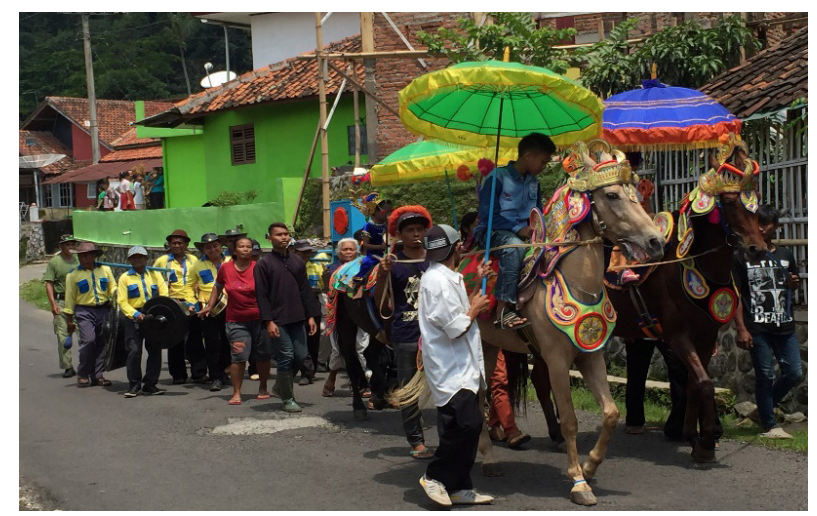

Gambar 2. Pelaksanaan kesenian Kuda Renggong oleh masyarakat. 
mengadakan acara kesenian ini apabila masyarakat mengadakan hajatan/selamatan. Kondisi ini seakan sudah menjadi tradisi yang mengakar dan menjadi agenda wajib bagi masyarakat.

\section{Simpulan}

Berdasarkan sejumlah temuan penelitian dan hasil analisis, nilai-nilai yang terpelihara dalam kesenian Kuda Renggong secara tidak langsung dapat membentuk karakter warga negara. Kebudayaan yang berkembang dalam masyarakat memiliki nilai dan fungsi tertentu. Nilai-nilai budaya berfungsi sebagai pedoman hidup manusia dalam masyarakat yang merupakan konsepkonsep mengenai apa yang hidup di alam pikiran sebagian besar warga masyarakat mengenai apa yang masyarakat anggap bernilai, berharga, dan penting dalam hidup. Nilai-nilai yang dianggap penting tersebut dapat terpelihara dan selalu menjadi pedoman hidup masyarakat. Nilai-nilai tersebut banyak terkandung dalam suatu budaya yang diciptakan oleh manusia. Salah satu nilai-nilai kehidupan yang dianut masyarakat juga ada dalam kesenian Kuda Renggong. Nilai-nilai tersebut supaya dapat terpelihara, maka masyarakat itu pula yang harus menjaga dan melestarikan budaya daerah mereka sendiri guna mempertahankan jati diri dan karakter dari warga negara tersebut.

Perubahan dinamis dan arus globalisasi yang tinggi menyebabkan masyarakat Indonesia yang memiliki banyak dan beragam kebudayaan kurang memiliki kesadaran akan pentingnya peranan budaya lokal ini dalam memperkokoh ketahanan budaya bangsa. Budaya lokal ini sesungguhnya dapat menjadikan bangsa Indonesia lebih bernilai dibandingkan bangsa-bangsa lain. Bangsa Indonesia seharusnya bisa lebih tanggap dan peduli lagi terhadap semua kebudayaan yang ada di Indonesia ini.

Arti kebudayaan dalam hal ini harus dipahami serta menjadikan keanekaragaman budaya yang ada di Indonesia sebagai sumber kekuatan untuk ketahanan budaya bangsa agar tetap terjaga dan tidak diambil oleh bangsa lain. Kekayaan bangsa Indonesia yang tidak ternilai harganya itu dan tidak pula dimiliki oleh bangsa-bangsa asing, maka sebagai generasi muda yang merupakan pewaris budaya bangsa, hendaknya memelihara seni budaya tersebut demi masa depan bangsa ini.

Dalam hal ini begitu pentingnya masyarakat dalam melestarikan budayanya sendiri guna membentuk karakter warga negara itu sendiri. Hal ini berarti sejalan dengan apa yang menjadi cita-cita dari Pemerintah Kabupaten Sumedang yang berupaya dalam melestarikan budaya daerah. Kondisi tersebut dibuktikan dengan dibuatnya Peraturan Bupati Nomor 113 Tahun 2009 Tentang Sumedang Puseur Budaya Sunda (SPBS), dan ini membuktikan bahwa Pemerintah Daerah Kabupaten Sumedang sangat peduli terhadap kelangsungan dan perkembangan budaya daerah yang ada di Kabupaten Sumedang khususnya dalam hal ini adalah kesenian Kuda Renggong yang merupakan salah satu kesenian unggulan di Kabupaten Sumedang. Pemerintah Daerah Kabupaten Sumedang juga mendapatkan dukungan dari para seniman Kuda Renggong dan juga dari masyarakat.

Berdasarkan hasil temuan, analisis, dan simpulan yang didapatkan peneliti dapat diberikan saran: (1) kepada generasi muda: diharapkan untuk memberi perhatian dan apresiasi terhadap budaya daerahnya sendiri khususnya dalam hal ini terhadap kesenian Kuda Renggong. Hal tersebut perlu dilakukan dengan tujuan kesenian Kuda Renggong tidak punah dan akan terus terpelihara dari generasi ke generasi berikutnya; (2) kepada seniman Kuda Renggong: diharapkan para seniman terus berjuang tanpa lelah dalam melestarikan kesenian Kuda Renggong agar tetap lestari. Dalam hal ini juga diharapkan PASKURES (Paguyuban Seni Kuda Renggong Kabupaten Sumedang) lebih sering mengadakan event yang berhubungan dengan kesenian Kuda Renggong guna mengedukasi masyarakat juga untuk ikut bersama-sama melestarikan budaya daerah sendiri. PASKURES juga diharapkan sering melakukan kerja sama dengan pemerintah daerah dalam mengadakan acara-acara yang berhubungan dengan kesenian Kuda Renggong dengan harapan masyarakat lebih mengenal dan terpacu ikut serta dalam upaya pelestarian budaya daerah; (3) kepada Pemerintah Daerah Kabupaten Sumedang: diharapkan 
pemerintah daerah melalui dinas yang terkait seperti DISDIKBUD dan DISPARPORA untuk terus memromosikan kesenian Kuda Renggong agar masyarakat tertarik untuk ikut berpartisipasi dalam upaya pelestarian budaya daerah. Promosi tersebut bisa berupa mengadakan event-event yang lebih sering lagi, tidak hanya jadi event tahunan. Bila memungkinkan bisa juga jadi event bulanan. Promosi yang lebih sering baik melalui media cetak maupun elektronik guna memberikan edukasi kepada masyarakat mengenai pentingnya pelestarian budaya daerah sendiri guna membentuk karakter dan jati diri masyarakat itu sendiri; (4) kepada para akademisi: diharapkan dengan adanya nilai-nilai yang terkandung dalam seni budaya daerah ini dapat dijadikan bahan sumber untuk etnopedagogic. Kondisi yang memungkinkan di sekolah bisa diajarkan mata pelajaran muatan lokal tentang keanekaragaman budaya daerah yang akan menjadikan cinta terhadap budaya daerah sendiri; dan (5) kepada peneliti selanjutnya diharapkan dapat melakukan kajian yang lebih mendalam mengenai nilai-nilai seni Kuda Renggong dalam membentuk karakter warga negara.

\section{Ucapan Terima Kasih}

Penulis ucapkan terima kasih kepada Mitra Bebestari Journal of Urban Society's Art yang telah memberi masukan guna menyempurnakan artikel ini dan para informan dalam penelitian ini yang telah memberikan kemudahan dalam proses penelitian untuk artikel ini.

\section{Kepustakaan}

Ardipal. 2015. "Peran Partisipan sebagai Bagian Infrastruktur Seni di Sumatera Barat: Perkembangan Seni Musik Talempong Kreasi”. Jurnal Resital, 16(1), pp.15-24.

Budimansyah, D., 2012. Perencanaan Pembelajaran Berbasis Karakter (Seri Pembinaan Profesionalisme Guru). Bandung: Widya Aksara Press.

Gufron, A., 2010. "Integrasi Nilai-nilai Karakter Bangsa pada Kegiatan Pembelajaran”.

\section{Cakrawala Pendidikan: Jurnal Ilmiah Pendidikan, 29, pp.13-24.}

Himawan, W., 2014. "Citra Budaya Melalui Kajian Historis dan Identitas: Perubahan Budaya Pariwisata Bali Melalui Karya Seni Lukis". Journal of Urban Society's Arts, 1(1), pp.74-88.

Himawan, W. \& Nugroho, A., 2014. "Visual Tradisi dalam Karya Seni Lukis Kontemporer Sebagai Wujud Artistik Pengaruh Sosial Budaya”. Journal of Urban Society's Arts, 1(4), pp.99-109.

Koentjaraningrat, 1974. Beberapa Pokok Antropologi Sosial. Jakarta: PT Dian Rakyat.

Koentjaraningrat, 1994. Metode-Metode Penelitian Masyarakat. Jakarta: Gramedia.

Lonto, A.L., 2015. "Pengembangan Model Pendidikan Karakter Berbasis Nilai SosioKultural pada Siswa SMA di Minahasa”. Jurnal Mimbar, 31(2), pp.319-327.

Miles, M. \& Huberman, A.M., 2007. Analisis Data Kualitatif, Buku Sumber tentang MetodeMetode Baru. Jakarta: Universitas Indonesia Press.

Parwito \& Drajat, K.T., 2013. "Kontruksi Identitas Kultural Masyarakat Pluralis dalam Terpaan Masyarakat Globalisasi”. Jurnal Mimbar, 29(1), pp.111-120.

Soekamto, S., 1983. Mengenal Sosiologi Hukum. Jakarta: PT. Raja Grafindo Persada.

Suhaida, D., 2014. "Pendidikan Kewarganegaraan dalam Penguatan Komitmen Kebangsaan pada Masyarakat Etnis Tionghoa Pontianak”. [Tesis]. Universitas Pendidikan Indonesia Bandung.

Suneki, S., 2012. "Dampak Globalisasi Terhadap Eksistensi Budaya Daerah”. Jurnal Ilmiah Civis, 2(1), p.239.

Utami, R.W., 2015. "Pengembangan Civic Culture Melalui Pendidikan Formal dan Budaya Lokal Masyarakat Suku Nuaulu: Studi Etnografi Pada Masyarakat Adat Suku Nuaulu di Pulau Seram, Negeri Nua Nea Kec. Amahai Kab. Maluku Tengah Prov. Maluku”. [Tesis]. Universitas Pendidikan Indonesia Bandung.

Widodo, J., 2009. "Meneguhkan Identitas Budaya Nasional”. Jurnal Bestari, 42, p.3. 